\title{
Cellular immune response and scanning electron microscopy in the evaluation of Moringa leaves aqueous extract effect on Cryptosporidium parvum in buffalo intestinal tissue explants
}

\author{
Dina Aboelsoued ${ }^{1}$ (D) Nagwa I. Toaleb ${ }^{1} \cdot$ Kadria N. Abdel Megeed $^{1} \cdot$ \\ Soad E. Hassan ${ }^{1} \cdot$ Sally Ibrahim ${ }^{2}$
}

Received: 25 January 2019/Accepted: 11 March 2019/Published online: 18 March 2019

(C) Indian Society for Parasitology 2019

\begin{abstract}
Cryptosporidium is an apicomplexan parasite of human and animals and is considered as an important cofactor in neonatal diarrhea. In this study, an explant culture was used as an in vitro model of buffalo intestine to evaluate the effect of Moringa leaves extract on Cryptosporidium parvum (C. parvum) oocysts using light and scanning electron microscopy and measuring IFN- $\gamma$, IL-12 and IL-14 in the culture supernatants. C. parvum oocysts were collected from naturally-infected calf feces, isolated, excysted and then co-inoculated with ileal tissue explants culture medium. The prepared Moringa leaves extract was then introduced to the infected tissues in the concentrations of $100 \mathrm{mg} / \mathrm{ml}$ and $300 \mathrm{mg} / \mathrm{ml}$. After $24 \mathrm{~h}$, tissues were collected and processed for light and scanning electron microscopy. Also, culture supernatants were collected for cytokines measurement. C. parvum parasitophorous vacuoles were found attached to the surface of tissue in Cryptosporidium-infected ileal tissue explants. High magnification imaging of ileal tissue explants using scanning electron microscopy showed that Moringa leaves extracts had a great effect on Cryptosporidium-infected ileal tissue explants. There was a high significant $(P<0.001)$ increase in IFN- $\gamma$, IL-12 and IL-14 (375, 275 and $90 \mathrm{pg} / \mathrm{ml}$, respectively) in the supernatants of infected non-treated ileal tissue explant culture plate wells compared to the control non-infected ones (74.66, 75 and $50 \mathrm{pg} / \mathrm{ml}$, respectively). A concentration of $100 \mathrm{mg} / \mathrm{ml}$ Moringa
\end{abstract}

Dina Aboelsoued

Dr.Dina.Aboelsoued@gmail.com

1 Department of Parasitology and Animal Diseases, National Research Centre, El Buhouth St, Dokki, Cairo, Egypt

2 Department of Animal Reproduction and AI, National Research Centre, El Buhouth St, Dokki, Cairo, Egypt extract exhibited the highest anticryptosporidial effect causing a significant decrease in IFN- $\gamma$, IL-12 and IL-14 levels $(225,150$ and $65 \mathrm{pg} / \mathrm{ml}$, respectively) compared with supernatants of infected non-treated ileal explant culture plate wells. In this study, explant culturing of buffalo ileal tissues allowed investigating the pathogenesis of cryptosporidiosis using light and scanning electron microscopy and studying changes in cytokine levels in tissues with and without Moringa leaves extract treatment. This model could help to understand the regulation of intestinal secretory and inflammatory responses, and could be useful for the screening of potential anticryptosporidial candidate compounds.

Keywords Cryptosporidium parvum · Buffaloes .

Tissue explant · Moringa - Scanning electron microscopy IFN- $\gamma \cdot$ IL-12 $\cdot$ IL-14

\section{Introduction}

Cryptosporidium parvum (C. parvum) is an apicomplexan intracellular intestinal parasite of human and animals which is responsible for many cases of cryptosporidiosis worldwide (Di Genova and Tonelli 2016). Cryptosporidiosis is one of the most important diseases of neonatal calves (Morsy et al. 2014). Infected animals suffer from profuse watery diarrhea, dehydration and in severe cases death can occur (Thomson et al. 2017). Also, infection can impair growth rates (Mallinath et al. 2009). This disease is difficult to manage due to environmentally stable oocysts, low infective dose and the broad range of hosts that can shed millions of sporulated oocysts (Thomson et al. 2017).

Furthurmore, there are no effective vaccines available to prevent the disease and the available treatment options 
often depend on rehydration therapy (Meganck et al. 2014). As the treatment modalities for cryptosporidiosis were limited, prevention and risk reduction became the most essential interferences (Chalmers and Davies 2010). Many therapeutic drugs were tested against cryptosporidiosis (Squire and Ryan, 2017) and they were suboptimal (Cabada and White 2010). The screening of numerous plants according to their therapeutic benefits leads to the discovery of novel and safe treatment alternatives for most diseases. One of such plants of a great medicinal value is Moringa oleifera (M. oleifera) (Ganatra Tejas et al. 2012). Studies had shown the composition of M. oleifera and its bioactive compounds including vitamins, flavonoids, essential amino acids, polyphenols and phenolic acids (Leone et al. 2015). Moringa leaves extracts exhibited pharmacological properties such as; antioxidant (Singh et al. 2009), immune-boosting (Miyachi et al. 2004), antiinflammatory, anti-diarrheal (Kesharwani et al. 2014), anthelmintic (Rastogi et al. 2009) and anti-protozoal activities (Köhler et al. 2002). In addition, Moringa had an ovicidal activity on Fasciola eggs (Hegazi et al. 2018; Kandil et al. 2018).

Epithelial cells are guarding cells in the mucosa, equipped with several defense mechanisms to kill pathogens, such as the induction of apoptosis and the production of chemokines and antimicrobial peptides for the induction of immune cells to the site of infection (Laurent and Lacroix-Lamandé 2017). In parasitic invasions, disturbances in the regulation of antibody production occur by $\mathrm{T}$ helper cells (Th), which promote local inflammatory reaction (Nickdel et al. 2001). Reports on the pathogenesis of cryptosporidiosis shown increased mRNA levels for cytokines as Interleukin-14 (IL-14) and Interferon- $\gamma$ (IFN$\gamma$ ) in human and murine intestinal cells infected with $C$. parvum (Tessema et al. 2009). IL-12 controls the type of the immune response and facilitates formation of a Th1 type response (Lang et al. 2007) and indirectly activates the antiparasitic, antimicrobial, and antitumor activity of macrophages and promotes the activity of natural killer cells (Akdis et al. 2016). IL-12 stimulates the production of IFN- $\gamma$ and activates lymphocyte cytotoxicity (Evering and Weiss 2006). IFN- $\gamma$ is involved in the protection against parasitic invasions (Matowicka-Karna et al. 2009) and the secretion of IFN- $\gamma$ in mice increased phagocytic activity of macrophages and this increased production of IFN- $\gamma$ was highly correlated with parasite virulence (Filisetti and Candolfi 2004). High IFN- $\gamma$ levels also activate promoted cytotoxic activities of other cells and induce apoptosis of epithelial cells in the mucosa (Zimmermann et al. 2011). During acute phase of infection, high amounts of IL-12 and IFN- $\gamma$ are produced to control the parasite in infected intestinal epithelial cells and these cytokines play a key role in the elimination process (Laurent and Lacroix-
Lamandé 2017). Most of studies describing the immune response induced by $C$. parvum parasites were demonstrated mainly in mice. Moreover, the immune response to C. parvum in human, buffaloes and cattle is still poorly understood. Studies in these hosts are required in order to identify the proper way to the control of cryptosporidiosis (Thomson et al. 2017). Immune response that underlies protection mechanisms against Cryptosporidium infection is a key strategy for vaccine development (Lemieux et al. 2018). In ruminants, scarce information present on immune mechanisms because of the difficulty of performing mechanistic studies due to large size of the animals and the limited immunological tools (Laurent and Lacroix-Lamandé 2017).

Many obstacles exist to the development of successive cures for Cryptosporidium infection, including difficulty in propagation of this parasite in vitro. Novel in vitro methods could help in propagation and might improve in vitro experiments to test novel treatments and vaccines (Randall et al. 2011). In this study, explant culturing of buffalo ileal tissue may allow investigating the pathogenesis of cryptosporidiosis using light and scanning electron microscopy and studying changes in INF- $\gamma$, IL-12 and IL-14 in tissues with and without Moringa leaves aqueous extract treatment. This could be a step forward in addressing the effect of parasitic infections in gastrointestinal tissues and their proper treatment.

\section{Materials and methods}

\section{Isolation of Cryptosporidium parvum oocysts}

C. parvum oocysts were collected from naturally-infected calf feces. Oocysts were concentrated by floatation in Sheather's sugar solution (Current and Reese 1986) and identified by modified Ziehl-Neelsen staining technique (Henriksen and Pohlenz 1981). Sedimented oocysts were collected and stored in a $2.5 \%$ potassium dichromate solution at $4{ }^{\circ} \mathrm{C}$. Before experiment, oocysts were washed from potassium dichromate, concentrated and counted in a phosphate buffered saline (PBS) solution using a Hemocytometer.

\section{Excystation of oocysts for tissue explants infection}

Excystation was performed as described by Varughese et al. (2014). Before experiments, oocysts were subjected to complete pre-treatment in acidified ( $\mathrm{pH}$ of 2.0) and prewarmed $\left(37^{\circ} \mathrm{C}\right) 1 \mathrm{X}$ Hank's Balanced Salt Solution calcium and magnesium free (HBSS) (Biowest, France) for 10 min at $37{ }^{\circ} \mathrm{C}$, followed by centrifugation and incubation with pre-warmed $\left(37^{\circ} \mathrm{C}\right)$ non-acidified $1 \mathrm{X}$ HBSS for 
$10 \mathrm{~min}$ at $37^{\circ} \mathrm{C}$, After one wash, the oocysts were resuspended in excystation medium, consisting of pre-warmed $\left(37^{\circ} \mathrm{C}\right)$ RPMI-1640 with L-glutamine (Biowest, France) containing $10 \%$ of fetal bovine serum (FBS) (BioWest, France) for $30 \mathrm{~min}$.

For infection, oocysts were transferred to $2 \mathrm{ml}$ microcentrifuge tubes and centrifuged at $4000 \times g$ at $4{ }^{\circ} \mathrm{C}$, for 3 min. The oocysts in the excystation medium were immediately used for infection.

\section{Collection of ileal tissues}

Buffalo ilea were collected from slaughterhouses in cold sterile saline solution supplemented with $1 \%$ (v/v) Gentamicin $50 \mu \mathrm{g} / \mathrm{ml}$ (Alex Co., Egypt). In Lab, ilea were washed one time in 70\% ethanol and then washed 4-5 times in a warm sterile saline solution $(\mathrm{NaCl} 0.9 \%)$.

\section{Tissue explants}

Ileal tissue explants were prepared as previously described by Randall et al. (2011) and Baydoun et al. (2017) with some modifications. In brief, Ileal parts were cut into small pieces (40-60 mg) with a scalpel, then some of these pieces were placed into 24-well culture plates (one piece/ well) containing $1.5 \mathrm{ml}$ RPMI 1640 medium with L-glutamine, supplemented with $1 \%$ Gentamicin $50 \mu \mathrm{g} / \mathrm{ml}$ and $10 \%$ FBS. The tissue explants were then incubated at $37{ }^{\circ} \mathrm{C}$ and $5 \% \mathrm{CO}_{2}\left(\mathrm{CO}_{2}\right.$ Incubator, NUAIRE, USA), for $2 \mathrm{~h}$. After that, ileal explants were transferred into new culture plates and medium were added as previously described.

\section{Moringa leaves extract}

M. oleifera leaves were purchased from local market, Cairo, Egypt. Moringa leaves were dried in shade and extract was prepared according to Harpone (1984). In brief, $200 \mathrm{gm}$ leaves were ground into powder, extracted in $2000 \mathrm{ml}$ of distilled water with stirring, left for $24 \mathrm{~h}$ in cold conditions $4{ }^{\circ} \mathrm{C}$ and filtered with sterile filter papers (Whattman No.1) then, dried under reduced pressure in a rotary evaporator at a temperature below $50{ }^{\circ} \mathrm{C}$ and stored at $-20{ }^{\circ} \mathrm{C}$ until use. Two concentrations of Moringa leaves extract were prepared for the experiment, by dissolving extract in distilled water, which were; $300 \mathrm{mg} / \mathrm{ml}$ and $100 \mathrm{mg} / \mathrm{ml}$.

\section{Experimental design}

The experimental design groups in 24-well culture plates (one piece of tissue explant/well) were divided into four plate well groups (6 wells/group); the 1st group contained non-infected ileal explants, the 2 nd contained ileal explants that co-inoculated with $C$. parvum oocysts (in a dose of $10^{4}$ pre-treated oocysts/well), the $3^{\text {rd }}$ contained ileal explants with $C$. parvum oocysts and $100 \mu$ l Moringa extract $(100 \mathrm{mg} / \mathrm{ml})$ and the last one contained ileal explants with Cryptosporidium oocysts and $100 \mu \mathrm{l}$ Moringa extract (300 mg/ml). After $24 \mathrm{~h}$, explants from all groups were collected and processed for microscopy. The supernatant medium were collected and kept in $-80{ }^{\circ} \mathrm{C}$ for determination of cellular immune response.

\section{Morphological analysis}

As described by Castro-Filice et al. (2014), ileal explants were fixed immediately in $10 \%$ formal saline and stained with hematoxylin and eosin (HE) staining. The ileal sections were examined for the detection of cryptosporidial stages microscopically at $1000 \times$ magnification by Optical Light Microscopy with Camera (Olympus Corporation, Japan).

\section{Scanning electron microscopy}

Samples were fixed in $2.5 \%$ glutaraldehyde. After processing following conventional method, specimens were critically point-dried using $\mathrm{CO}_{2}$ and coated with gold. Observations were made using scanning electron microscope (QUANTA FEG 250, USA).

\section{Assessment of cytokine levels}

Levels of IFN- $\gamma$, IL-12 and IL-14 in ileal explant culture supernatants were measured (Silberer et al. 2008) by a sandwich ELISA kit according to the manufacturer's instructions (Sunlong Biotech Co., Ltd., China). Optical density was measured at $450 \mathrm{~nm}$ with a Microplate Reader (BioTek Instruments, USA). The concentrations were calculated from standard curves that were performed in the same assay.

\section{Statistical analysis}

Data of INF- $\gamma$, IL-12 and IL-14 concentrations were expressed as mean \pm SD in three independent experiments, each done in quadruplicate. Comparison between the means of different parameters was evaluated using oneway ANOVA test according to Snedecor and Cochran (1980). All results were analyzed using Statistical SPSS for Windows, issue 15.8 . 


\section{Results}

\section{Morphological analysis}

Normal structure was found in tissue explants from noninfected groups (Fig. 1). As shown in Figs. 2, 3 and 4, parasitophorous vacuoles of $C$. parvum were found on the surface of tissue in Cryptosporidium-infected ileal tissue explants (Fig. 2) and also were found on the surface of tissue in Moringa leaves extract (100 and $300 \mathrm{mg} / \mathrm{ml}$ ) treated Cryptosporidium-infected ileal tissue explants (Figs. 3, 4, respectively), however, vacuoles were smaller in size in Moringa $(300 \mathrm{mg} / \mathrm{ml})$ treated tissues than other infected ones.

\section{Scanning electron microscopy}

High magnification imaging of ileal tissue explants using scanning electron microscopy showed normal structure of healthy non-infected ileal tissue explants (Fig. 5) and parasitophorous vacuoles of $C$. parvum on the surface of infected ileal tissue explants (Fig. 6). In Moringa leaves extract $(100 \mathrm{mg} / \mathrm{ml})$ treated infected ileal tissue explants, irregular shaped parasitophorous vacuoles of $C$. parvum were found with granulated surface (Fig. 7) and little shrinkage (Fig. 8) in comparison to normal non-treated ones. In Moringa leaves extract $(300 \mathrm{mg} / \mathrm{ml})$ treated Cryptosporidium-infected ileal tissue explant, vacuolated (A), irregular shaped and granulated (B), cracked and shrunken (C and D) and atrophic (E) parasitophorous vacuoles in comparison to normal non-treated vacuoles (Fig. 9).

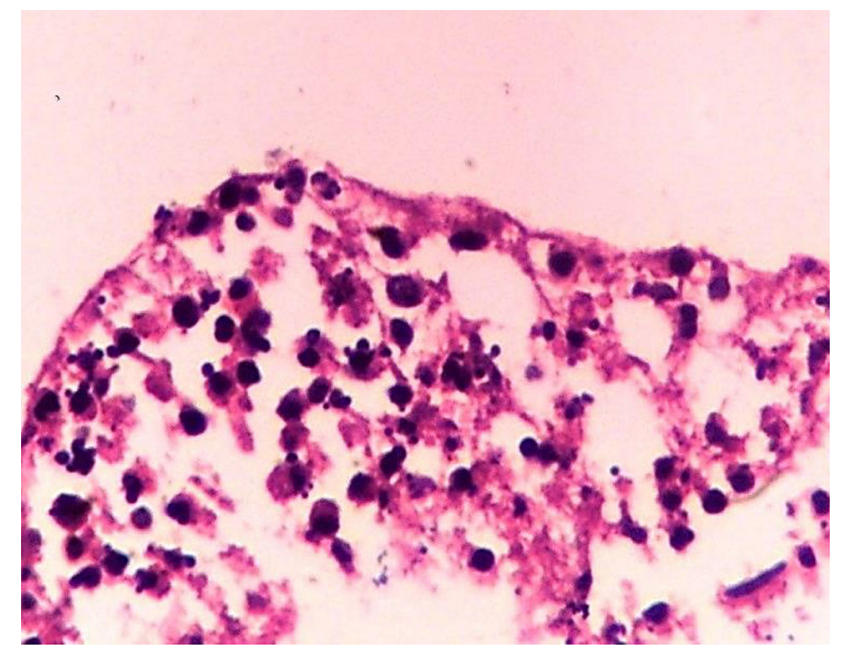

Fig. 1 Ileal tissue explant showing normal structure, sections stained with hematoxylin and eosin $(\mathrm{HE}), \times 1000$

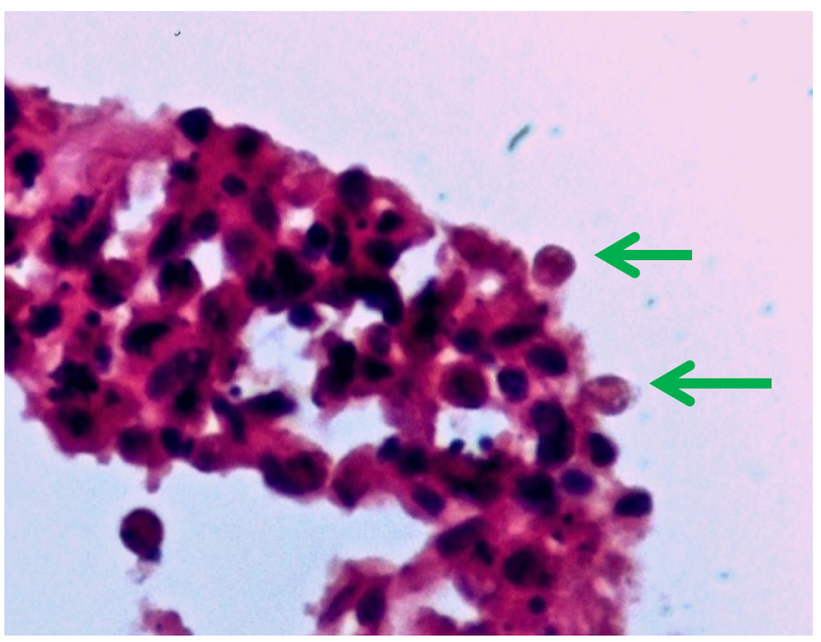

Fig. 2 Cryptosporidium-infected ileal tissue explant showing parasitophorous vacuoles of $C$. parvum on the surface of tissue (arrows), sections stained with HE, $\times 1000$

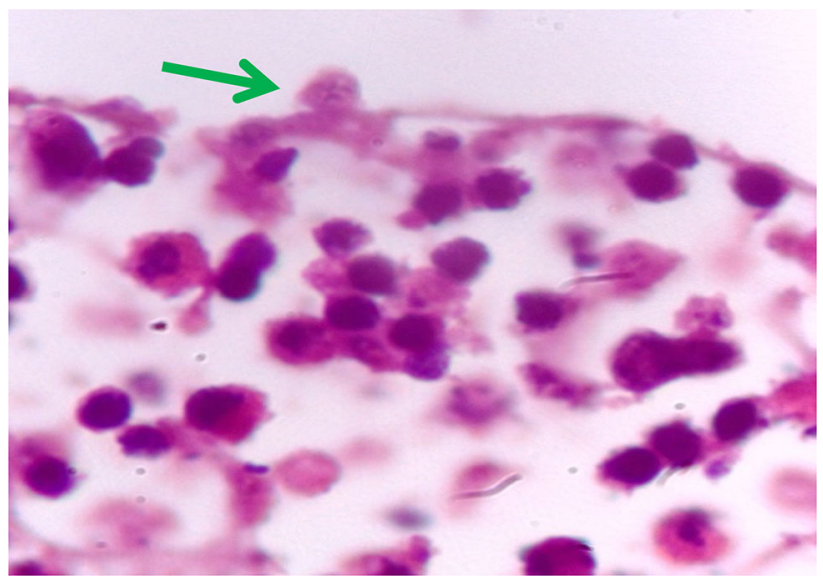

Fig. 3 Moringa leaves extract $(100 \mathrm{mg} / \mathrm{ml})$ treated Cryptosporidiuminfected ileal tissue explant showing parasitophorous vacuoles of $C$. parvum on the surface of tissue (arrow), sections stained with $\mathrm{HE}$, $\times 1000$

\section{Cellular immune response}

As shown in Table 1, there was a high significant $(P<0.001)$ increase in IFN- $\gamma$, IL-12 and IL-14 in the supernatants of infected non-treated ileal explant culture plate wells compared to the control non-infected ones. Treatment of $C$. parvum infection by a concentration of $100 \mathrm{mg} / \mathrm{ml}$ Moringa extract decreased the levels of IFN- $\gamma$, IL-12 and IL-14 significantly $(P<0.001)$. Levels of IFN$\gamma$, IL-12 and IL-14 were higher in culture supernatants that were treated with $300 \mathrm{mg} / \mathrm{ml}$ Moringa than infected treated $100 \mathrm{mg} / \mathrm{ml}$ but still lower than the control infected nontreated ileal explant culture plate wells. 


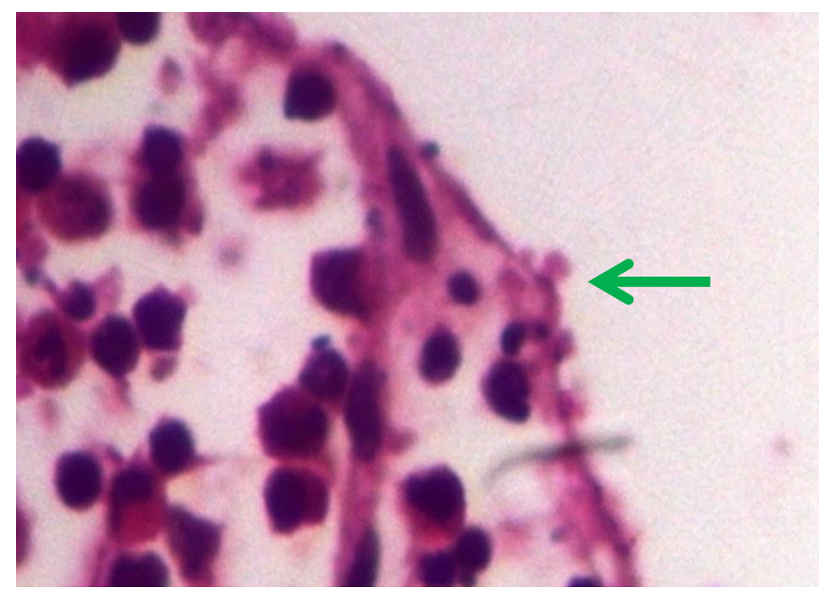

Fig. 4 Moringa leaves extract $(300 \mathrm{mg} / \mathrm{ml})$ treated Cryptosporidiuminfected ileal tissue explant showing smaller parasitophorous vacuoles of $C$. parvum as compared with those on infected non-treated tissues (arrow), sections stained with HE, $\times 1000$

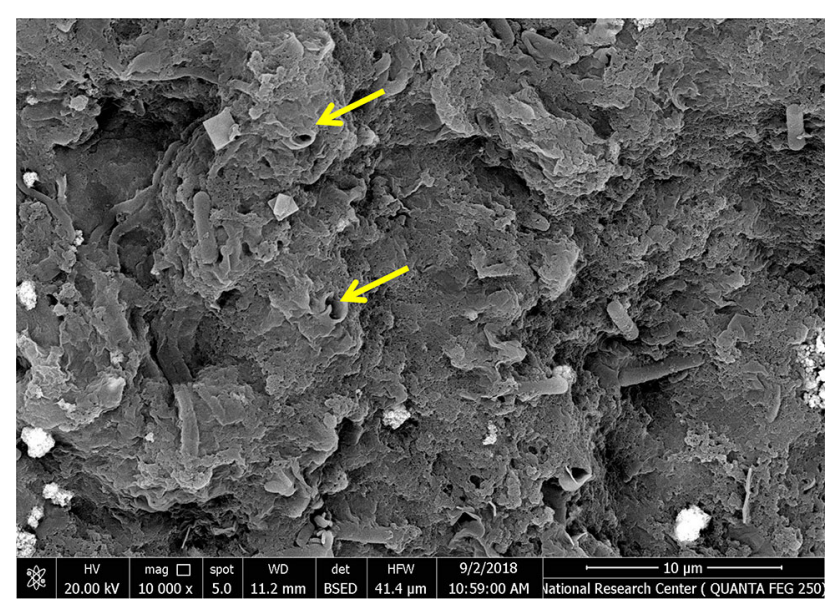

Fig. 5 Scanning electron micrograph of healthy non-infected ileal tissue explant showing normal structure of ileal tissue. Arrows: pores of villi

\section{Discussion}

Cryptosporidium effect on tissues as well as its control in vitro was difficult and was traditionally assessed in vivo. Although extensive studies using various animal models had discussed the host immune response against Cryptosporidium infection, the ability of these models was still limited. The progress in animal infection models had been impaired to some extent by the infection acquisition early after birth (McDonald et al. 2000). Regarding host response to infection, the clinical picture in rodents was different from other hosts, as mice did not get diarrhea after infection (Pantenburg et al. 2008). Our results validated the tissue explant as a model to test the anticryptosporidial effect of Moringa in a buffalo experimental setting as close to clinical testing as possible. This tool could offer an

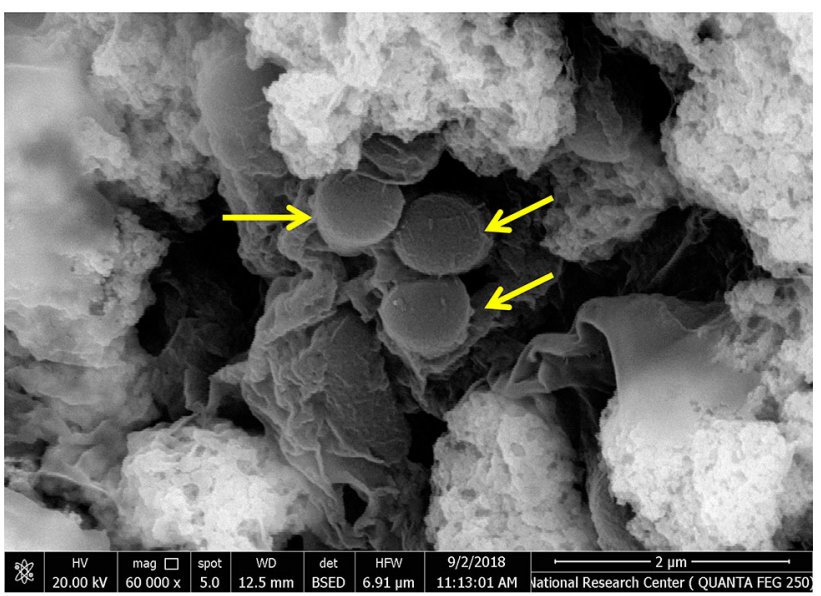

Fig. 6 Scanning electron micrograph of Cryptosporidium-infected ileal tissue explant showing parasitophorous vacuoles of $C$. parvum on the surface of tissue (arrows)

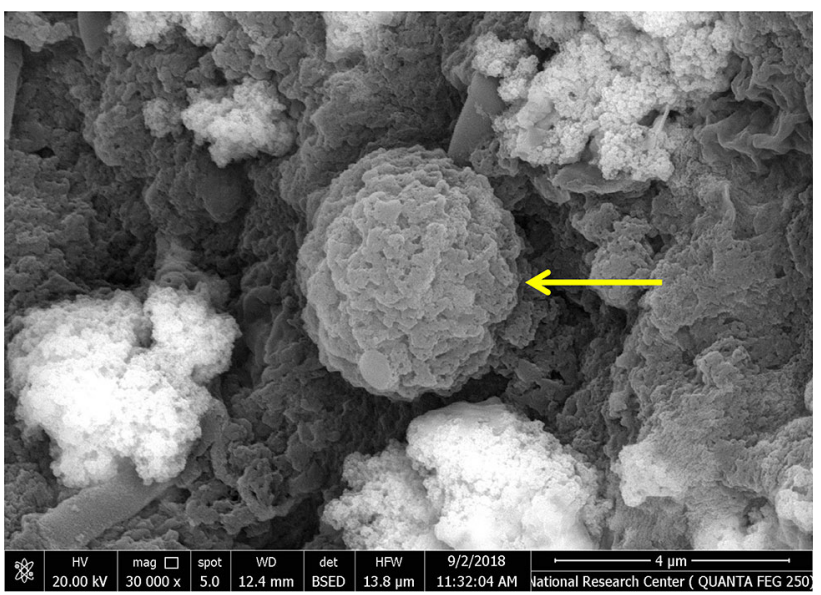

Fig. 7 Scanning electron micrograph of Moringa leaves extract $(100 \mathrm{mg} / \mathrm{ml})$ treated Cryptosporidium-infected ileal tissue explant showing irregular shaped $C$. parvum oocyst with granulated surface in comparison to normal non-treated vacuoles (arrow)

in vitro model that mimicking in vivo conditions, capturing the preferred site of infection and helping to expand the knowledge about infectivity, pathogenesis and treatment trials of this parasite. Randall et al. (2011) stated that the explant culture of gastrointestinal tissue offered an alternative approach. The explant tissue is comprised of epithelial, stromal and resident leukocytes, as occurs in vivo and thus, it can be used as a functional representation of the selected tissue (Nash et al. 2008).

In the intestinal lumen, the oocyst releases sporozoites, which attach apical surface of host cells and are enveloped. Active invasion mechanism progresses within the host cell plasmalemma, where, they form a parasitophorous vacuole (Khan et al. 2018). In this study, Cryptosporidium parasitophorous vacuoles were found attached to the surface of tissue in Cryptosporidium-infected non-treated and 


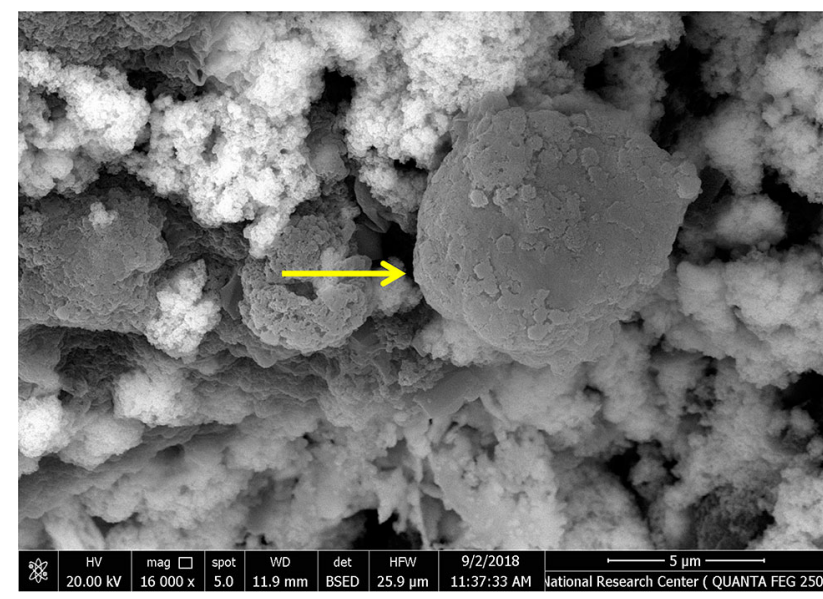

Fig. 8 Scanning electron micrograph of Moringa leaves extract $(100 \mathrm{mg} / \mathrm{ml})$ treated Cryptosporidium-infected ileal tissue explant showing irregular shaped $C$. parvum oocyst with granulated surface in comparison to normal non-treated vacuoles (arrow)

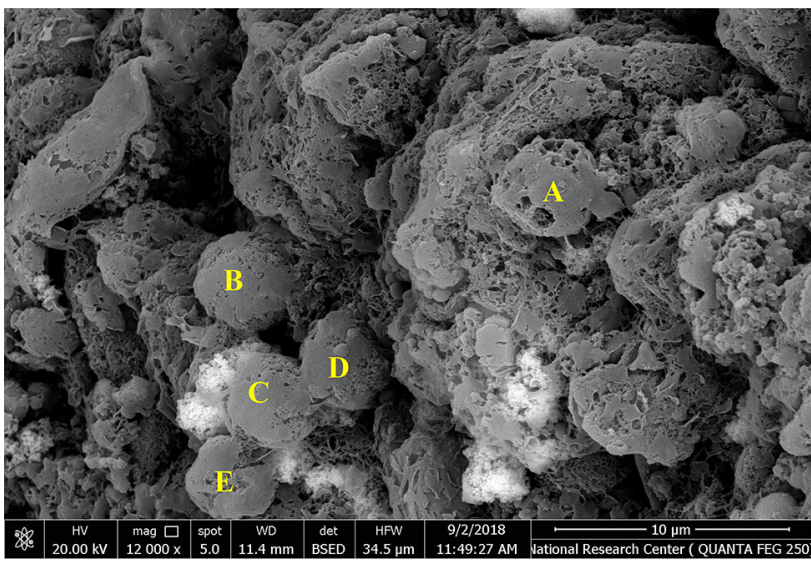

Fig. 9 Scanning electron micrograph of Moringa leaves extract $(300 \mathrm{mg} / \mathrm{ml})$ treated Cryptosporidium-infected ileal tissue explant showing vacuolated (A), irregular shaped and granulated (B), cracked and shrunken $(\mathrm{C} \& \mathrm{D})$ and atrophic (E) parasitophorous vacuoles of $C$. parvum in comparison to normal non-treated vacuoles
Moringa leaves extract (100 and $300 \mathrm{mg} / \mathrm{ml}$ ) treated Cryptosporidium-infected ileal tissue explants indicating success of the progression of $C$. parvum infection on the ileal tissue explants. Based on morphological examination, high magnification imaging of ileal tissue explants cultured in RPMI-1640/FBS medium using scanning electron microscopy showed that Moringa leaves extract $(300 \mathrm{mg} /$ $\mathrm{ml}$ ) had a great effect on Cryptosporidium-infected ileal tissue explants. However, the dose of $100 \mathrm{mg} / \mathrm{ml}$ also affected the Cryptosporidium vacuoles giving granulated, irregular shaped and shrunken parasitophorous vacuoles. This effect on parasitophorous vacuoles of the parasite might be due to the presence of saponins, tannins and phenolic compounds in Moringa leaves which could interfere with glycoprotein of the cell surface of the parasite and cause its death (Bauri et al. 2015).

IFN- $\gamma$ and IL-12 appear to be important mediators in host resistance to cryptosporidiosis in neonatal and adult mice, which were deficient for IL-12 and IFN- $\gamma$, were more susceptible to $C$. parvum infection (Laurent and LacroixLamandé 2017). IL-12 is required for inducing IFN- $\gamma$-dependent immunity against $C$. parvum in mice that lacked $\mathrm{T}$ and B cells (Korbel et al, 2011). In the present study, IFN$\gamma$, IL-12 and IL-14 in the supernatants of infected nontreated groups were more than those of the control noninfected ones. Our results suggested that the C. parvum infection induced a Th1 response, a finding that agreed with Li et al. (2013). Also, our results agreed with Marchi et al. (2014) who reported that IL-12 and IFN- $\gamma$ promoted development of naïve CD4+ T cells into Th1 cells which help in the killing of intracellular microorganisms, such as; Cryptosporidium spp., by stimulating phagocytosis and neutrophil degranulation. Although neonates had limited adaptive immunity, Ferret-Bernard et al. (2011) and Auray et al. (2013) found that most animal models susceptible to C. parvum infection release large amounts of IL-12. In this

Table 1 Levels of IFN- $\gamma$, IL-12 and IL-14 in culture supernatants of the tested groups

\begin{tabular}{|c|c|c|c|c|c|}
\hline \multirow[t]{3}{*}{ Parameter } & \multicolumn{4}{|l|}{ Groups } & \multirow[t]{3}{*}{ F-value } \\
\hline & \multirow[t]{2}{*}{ Healthy non-infected } & \multicolumn{3}{|c|}{ Cryptosporidium parvum infected } & \\
\hline & & Non-treated & Moringa $(100 \mathrm{mg} / \mathrm{ml})$ treated & Moringa $(300 \mathrm{mg} / \mathrm{ml})$ treated & \\
\hline $\mathrm{INF}-\gamma(\mathrm{pg} / \mathrm{ml})$ & $74.66 \pm 0.53^{\mathrm{d}}$ & $375 \pm 1.44^{\mathrm{a}}$ & $225 \pm 0.16^{\mathrm{c}}$ & $300 \pm 0.8^{\mathrm{b}}$ & $86,672.9 *$ \\
\hline $\mathrm{IL}-12(\mathrm{pg} / \mathrm{ml})$ & $75 \pm 0.82^{\mathrm{d}}$ & $275 \pm 0.81^{\mathrm{a}}$ & $150 \pm 0.63^{\mathrm{c}}$ & $200 \pm 2.45^{\mathrm{b}}$ & $11,333.3 *$ \\
\hline IL-14 (pg/ml) & $50 \pm 2.45^{\mathrm{d}}$ & $90 \pm 2.16^{\mathrm{a}}$ & $65 \pm 0.82^{\mathrm{c}}$ & $75 \pm 2.16^{\mathrm{b}}$ & $283.3 *$ \\
\hline
\end{tabular}

All values are mean \pm standard deviation (SD)

*Significant differences at $P<0.001$

Means within rows with different letters are statistically different 
study, the treatment of $C$. parvum infection by a concentration of $100 \mathrm{mg} / \mathrm{ml}$ Moringa extract decreased the levels of IFN- $\gamma$, IL-12 and IL-14 significantly $(P<0.001)$, while, they were higher in culture supernatants of $300 \mathrm{mg} / \mathrm{ml}$ Moringa but still lower than the infected non-treated group. Elevated cytokines detected in the infected non-treated tissue supernatants, as a result of infection, indicated inflammation. In this context, it is noteworthy that Moringa reduced the inflammatory response of $C$. parvum infected and treated ileal tissues. These results might be explained by Kesharwani et al. (2014) who clarified the anti-inflammatory and anti-diarrheal effect of $M$. oleifera. The differences in cytokine levels in the Moringa treated groups might be explained by Olayemi et al. (2016) who found that tissues showed congestion and alterations after the administration of the higher doses of Moringa leaves. However, these differences need further studies to understand regulatory mechanisms. In general, the anticryptosporidial effect of Moringa treatment, reported in our study, detected by microscopy and measured cytokines might be due to its enormous medicinal potential and inhibitory activities against several microorganisms (Farooq et al. 2012) including tannins, flavonoids, alkaloids, saponins, carbohydrates and steroids which were reported in M. oleifera leaves (Cabardo and Portugaliza 2017). Stohs and Hartman (2015) found that aqueous extracts of M. oleifera leaves exhibited various biological activities including tissue protective and antioxidant properties, in addition, these extracts were shown to be safe to use based on safety studies in animal models.

In conclusion, our results validated the buffalo ileal tissue explant as a model to test the anticryptosporidial effect of Moringa in a buffalo experimental setting as close to clinical testing as possible. It was helpful in investigating the pathogenesis of cryptosporidiosis using light and scanning electron microscopy and studying changes in INF- $\gamma$, IL-12 and IL-14 in tissues with and without Moringa treatment. The concentration of $100 \mathrm{mg} / \mathrm{ml}$ Moringa leaves extract had a great anticryptosporidial effect than the concentration of $300 \mathrm{mg} / \mathrm{ml}$. This was a preliminary work and further studies should be established using different concentrations at different periods. This model could offer a better understanding of the regulation of intestinal secretory and inflammatory responses, and could be useful for the screening of potential anti-parasitic candidate compounds.

Acknowledgements The authors are grateful to National Research Centre, Egypt, for the fund support of this work via the research grant (No. AR111207). The authors are thankful for Prof. Dr. Youssef Fawzy Ahmed, Professor of Reproductive Pathology, National Research Centre, for his continuous help in the histopathological part of this study.
Author contributions All authors prepared the research plan and the design of experiments. KNA and DA separated C. parvum oocysts from calf fecal samples and prepared Moringa extract and the selected doses. DA and SI collected ileal tissues, propagated the infection and tested the treatments. SI collected tissue explants and culture supernatants. KNA and DA examined tissue explants by light microscopy. SEH and DA examined explants by scanning electron microscopy. NIT, DA and SEH measured cytokines in culture supernatants. DA and NIT analyzed, interpreted the data and prepared the manuscript. All authors have critically read and approved the final manuscript.

\section{Compliance with ethical standards}

Conflict of interest The authors declare that they have no conflicts or competing interests.

\section{References}

Akdis M, Aab A, Altunbulakli C, Azkur K, Costa RA, Crameri R et al (2016) Interleukins (from IL-1 to IL-38), interferons, transforming growth factor $\beta$, and TNF- $\alpha$ : receptors, functions, and roles in diseases. J Allergy Clin Immunol 138(4):984-1010. https://doi.org/10.1016/j.jaci.2016.06.033

Auray G, Facci MR, van Kessel J, Buchanan R, Babiuk LA, Gerdts V (2013) Porcine neonatal blood dendritic cells, but not monocytes, are more responsive to TLRs stimulation than their adult counterparts. PLoS ONE 8(5):e59629. https://doi.org/10.1371/ journal.pone.0059629

Bauri RK, Tigga MN, Kullu SS (2015) A review on use of medicinal plants to control parasites. Ind J Nat Prod Resour 6(4):268-277

Baydoun M, Vanneste SB, Creusy C, Guyot K, Gantois N, Chabe M et al (2017) Three-dimensional (3D) culture of adult murine colon as an in vitro model of cryptosporidiosis: proof of concept. Sci Rep 7(1):17288. https://doi.org/10.1038/s41598-01717304-2

Cabada MM, White AC (2010) Treatment of cryptosporidiosis: do we know what we think we know? Curr Opin Infect Dis 23:494-499. https://doi.org/10.1097/qco.0b013e32833de052

Cabardo DE, Portugaliza HP (2017) Anthelmintic activity of Moringa oleifera seed aqueous and ethanolic extracts against Haemonchus contortus eggs and third stage larvae. Int J Vet Sci Med 5(1):30-34. https://doi.org/10.1016/j.ijvsm.2017.02.001

Castro-Filice LS, Barbosa BS, Angeloni MB, Silva NM, Gomes AO, Alves CMOS et al (2014) Azithromycin is able to control Toxoplasma gondii infection in human villous explants. J Transl Med 12:132-143. https://doi.org/10.1186/1479-5876-12-132

Chalmers RM, Davies AP (2010) Minireview: clinical cryptosporidiosis. Exp Parasitol 124(1):138-146. https://doi.org/10.1016/ j.exppara.2009.02.003

Current WL, Reese NC (1986) A comparison of endogenous development of three isolates of Cryptosporidium in suckling mice. J Protozool 33:98-108

Di Genova BM, Tonelli RR (2016) Infection strategies of intestinal parasite pathogens and host cell responses. Front Microbiol 7:256, 16 pages. https://doi.org/10.3389/fmicb.2016.00256

Evering T, Weiss LM (2006) The immunology of parasite infections in immunocompromised hosts. Parasite Immunol 28(11): 549-565. https://doi.org/10.1111/j.1365-3024.2006.00886.x

Farooq F, Rai M, Tiwari A, Khan A, Farooq S (2012) Medicinal properties of Moringa oleifera: an overview of promising healer. JMPR 6(27):4368-4374. https://doi.org/10.5897/jmpr012.279

Ferret-Bernard S, Lacroix-Lamande S, Remot A, Metton C, Bernardet N, Charley B et al (2011) Mesenteric lymph node cells from neonates present a prominent IL-12 response to $\mathrm{CpG}$ 
oligodeoxynucleotide via an IL-15 feedback loop of amplification. Vet Res 42:19. https://doi.org/10.1186/1297-9716-42-19

Filisetti D, Candolfi E (2004) Immune response to Toxoplasma gondii. Ann Ist Super Sanita 40(1):71-80

Ganatra Tejas H, Joshi UH, Bhalodia PN, Desai TR, Tirgar PR (2012) A panoramic view on pharmacognostic, pharmacological, nutritional, therapeutic and prophylactic values of Moringa oleifera lam. IRJP 3(6):1-7

Harpone JB (1984) Phytochemical methods, 2nd edn. Chapman and Hall, New York

Hegazi AG, Abdel Megeed KN, Hassan SE, Abdelaziz MM, Toaleb NI, El Shanawany EE, Aboelsoued D (2018) Comparative ovicidal activity of Moringa oleifera leaf extracts on Fasciola gigantica eggs. Vet World 11(2):215-220. https://doi.org/ 10.14202/vetworld.2018.215-220

Henriksen SA, Pohlenz JF (1981) Staining of cryptosporidia by a modified Ziehl-Neelsen technique. Acta Vet Scand 22:594-596

Kandil OM, Hassan NMF, Sedky D, Ata EB, Nassar SA, Shalaby HA, Nanev V, Tsocheva-Gaytandzhieva N, Gabrashanska M (2018) Anthelmintic efficacy of Moringa oleifera seed methanolic extract against Fasciola hepatica. J Parasit Dis 42(3):391-401. https://doi.org/10.1007/s12639-018-1014-y

Kesharwani S, Prasad P, Roy A, Sahu RK (2014) An overview on phytochemistry and pharmacological explorations of Moringa oleifera. UK J Pharm Biosci 2(1):34-41. https://doi.org/ 10.20510/ukjpb/2/i1/91151

Khan A, Shaik JS, Grigg ME (2018) Genomics and molecular epidemiology of Cryptosporidium species. Acta Trop 184:1-14. https://doi.org/10.1016/j.actatropica.2017.10.023

Köhler I, Jenett-Siems K, Siems K, Hernández MA, Ibarra RA et al (2002) In vitro antiplasmodial investigation of medicinal plants from El Salvador. Z Naturforschung 57:277-281

Korbel DS, Barakat FM, Di Santo JP, McDonald V (2011) CD4 + T cells are not essential for control of early acute Cryptosporidium parvum infection in neonatal mice. Infect Immun 79(4): 1647-1653. https://doi.org/10.1128/iai.00922-10

Lang C, Groß U, Lüder CGK (2007) Subversion of innate and adaptive immune responses by Toxoplasma gondii. Parasitol Res 100(2):191-203. https://doi.org/10.1007/s00436-006-0306-9

Laurent F, Lacroix-Lamandé S (2017) Innate immune responses play a key role in controlling infection of the intestinal epithelium by Cryptosporidium. Int J Parasitol 47:711-721. https://doi.org/ 10.1016/j.ijpara.2017.08.001

Lemieux MW, Sonzogni-Desautels K, Ndao M (2018) Lessons learned from protective immune responses to optimize vaccines against cryptosporidiosis. Pathogens 7(1):E2. https://doi.org/ $10.3390 /$ pathogens 7010002

Leone A, Spada A, Battezzati A, Schiraldi A, Aristil J et al (2015) Cultivation, genetic, ethnopharmacology, phytochemistry and pharmacology of Moringa oleifera leaves: an overview. Int J Mol Sci 16:12791-12835. https://doi.org/10.3390/ijms160612 791

Li S, Li W, Yang Z, Song S, Yang J, Gong P et al (2013) Infection of cattle with Cryptosporidium parvum: mast cell accumulation in small intestine mucosa. Vet Pathol 50(5):842-848. https://doi.org/ $10.1177 / 0300985813476055$

Mallinath RHK, Chikkachowdappa PG, Gowda AKJ, D'Souza PE (2009) Studies on the prevalence of cryptosporidiosis in bovines in organized dairy farms in and around Bangalore. Vet Arhiv 79(5):461-470

Marchi LF, Sesti-Costa R, Ignacchiti MD, Chedraoui-Silva S, Mantovani B (2014) In vitro activation of mouse neutrophils by recombinant human interferon-gamma: increased phagocytosis and release of reactive oxygen species and pro-inflammatory cytokines. Int Immunopharmacol 18:228-235. https://doi.org/ 10.1016/j.intimp.2013.12.010
Matowicka-Karna J, Dymicka-Piekarska V, Kemona H (2009) Does Toxoplasma gondii infection affect the levels of IgE and cytokines (IL-5, IL-6, IL-10, IL-12, and TNF-alpha)? Clin Dev Immunol 2009:142-145. https://doi.org/10.1155/2009/374696

McDonald V, Smith R, Robinson H, Bancroft G (2000) Host immune responses against Cryptosporidium. Petry F (ed) Cryptosporidiosis and microsporidiosis. Contrib Microbiol. Basel, Karger 6: 75-91

Meganck V, Hoflack G, Opsomer G (2014) Advances in prevention and therapy of neonatal dairy calf diarrhoea: a systematical review with emphasis on colostrum management and fluid therapy. Acta Vet Scand 56:75. https://doi.org/10.1186/ s13028-014-0075-x

Miyachi K, Fritzler MJ, Tan EM (2004) Benzyl isothiocyanate inhibits excessive superoxide generation in inflammatory leukocytes: implication for prevention against inflammation-related carcinogenesis. Carcinogenesis 25:567-575. https://doi.org/10.1093/ carcin/bgh051

Morsy GH, Abdel Megeed KN, Hammam AM, Seliem MME, Khalil FAM, Aboelsoued D (2014) Prevalence of Cryptosporidium infection in buffalo calves with special reference to urea and creatinine levels. Glob Vet 13(5):662-667

Nash D, Lane E, Herath S, Sheldon M (2008) Endometrial explant culture for characterizing equine endometritis. Am J Reprod Immunol 59(2):105-117. https://doi.org/10.1111/j.1600-0897. 2007.00548.x

Nickdel MB, Roberts F, Brombacher F, Alexander J, Roberts CW (2001) Counter-protective role for interleukin-5 during acute Toxoplasma gondii infection. Infect Immun 69(2):1044-1052. https://doi.org/10.1128/IAI.69.2.1044-1052.2001

Olayemi AT, Olanrewaju MJ, Oloruntoba AC (2016) Toxicological evaluation of Moringa oleifera Lam seeds and leaves in Wistar rats. Pharmacogn Commn 6(2):100-111. https://doi.org/ $10.5530 /$ pc. 2016.2 .8

Pantenburg B, Dann SM, Wang H, Robinson P, Castellanos-Gonzalez A, Lewis DE et al (2008) Minireview, Intestinal immune response to human Cryptosporidium sp. infection. Infect Immun 76(1):23-29. https://doi.org/10.1128/iai.00960-07

Randall KJ, Turton J, Foster JR (2011) Explant culture of gastrointestinal tissue: a review of methods and applications. Cell Biol Toxicol 27:267-284. https://doi.org/10.1007/s10565-011-9187-5

Rastogi T, Bhutda V, Moon K, Aswar PB, Khadabadi SS (2009) Comparative studies on anthelmintic activity of Moringa oleifera and Vitex negundo. Asian J Res Chem 2:181-182

Silberer J, Ihorst G, Kopp MV (2008) Cytokine levels in supernatants of whole blood and mononuclear cell cultures in adults and neonates reveal significant differences with respect to interleukin-13 and interferon-gamma. Pediatr Allergy Immunol 19(2):140-147. https://doi.org/10.1111/j.1399-3038.2007.00 605.x

Singh BN, Singh BR, Singh RL, Prakash D, Dhakarey R, Upadhyay G, Singh HB (2009) Oxidative DNA damage protective activity, antioxidant and anti-quorum sensing potentials of Moringa oleifera. Food Chem Toxicol 47:1109-1116. https://doi.org/ 10.1016/j.fct.2009.01.034

Snedecor GW, Cochran WG (1980) Statistical methods, 7th edn. Iowa State University Press, Ames

Squire SA, Ryan U (2017) Cryptosporidium and Giardia in Africa: current and future challenges. Parasit Vectors 10:195

Stohs SJ, Hartman MJ (2015) Review of the safety and efficacy of Moringa oleifera. Phytother Res 29:796-804. https://doi.org/ $10.1002 /$ ptr.5325

Tessema TS, Schwamb B, Lochner M, Förster I, Jakobi V, Petry F (2009) Dynamics of gut mucosal and systemic Th1/Th2 cytokine responses in interferon-gamma and interleukin-12p40 knockout mice during primary and challenge Cryptosporidium parvum 
infection. Immunobiology 214:454-466. https://doi.org/10.1016/ j.imbio.2008.11.015

Thomson S, Hamilton CA, Hope JC, Katzer F, Mabbott NA, Morrison LJ, Innes EA (2017) Bovine cryptosporidiosis: impact, hostparasite interaction and control strategies. Vet Res 48:42. https://doi.org/10.1186/s13567-017-0447-0

Varughese EA, Bennett-Stamper CL, Wymer LJ, Yadav JS (2014) A new in vitro model using small intestinal epithelial cells to enhance infection of Cryptosporidium parvum. J Microbiol Methods 106:47-54. https://doi.org/10.1016/j.mimet.2014.07. 017
Zimmermann M, Koreck A, Meyer N, Basinski T, Meiler F, Burgler S et al (2011) TNF-like weak inducer of apoptosis (TWEAK) and TNF- $\alpha$ cooperate in the induction of keratinocyte-apoptosis. J Allergy Clin Immunol 127(200-207):e1-e10. https://doi.org/ 10.1016/j.jaci.2010.11.005

Publisher's Note Springer Nature remains neutral with regard to jurisdictional claims in published maps and institutional affiliations. 